\title{
PLASMA HORMONE LEVELS AND FERTILITY IN PIGS INDUCED TO SUPEROVULATE WITH PMSG*
}

\author{
H. D. GUTHRIE, $\dagger$ D. M. HENRIGKS $\ddagger$ AND D. L. HANDLIN \\ Departments of Food Science and Animal Science, \\ Clemson University, Clemson, South Carolina 29631, U.S.A.
}

(Received 14th February 1974)

Summary. Seventy-one mature gilts were allocated to a $3 \times 2 \times 2$ factorial experiment consisting of three doses of PMSG $(0,600$ or 1200 i.u.), two levels of food intake on the lst day of oestrus (none or double the normal daily amount of food), and two times of autopsy after mating (Day 6 or Day 24). The PMSG was administered by a single subcutaneous injection on Day 15 of the oestrous cycle and animals were mated on the first 2 days of the subsequent oestrus. Blood samples were collected in order to assess the effects of PMSG and superovulation on the secretion of oestrogen, $\mathrm{LH}$, and progesterone. Ovulation rate was significantly increased by PMSG treatment $(P \leqslant 0 \cdot 001)$ but was not affected by food intake at oestrus. The number of normal embryos at slaughter on Day 6 or Day 24 after mating was significantly increased by PMSG treatment compared to that in the control animals, but embryonic losses by Day 24 were greatly increased in the gilts treated with PMSG. The plasma oestrogen concentration before oestrus was increased by PMSG treatment. The magnitude of the LH surge on the 1st day of oestrus was not. affected by PMSG, but oestrus and the preovulatory LH surge were advanced by about 1 day. Mean plasma progesterone concentrations after mating were increased by PMSG treatment.

\section{INTRODUGTION}

Increased ovulation rates have been obtained in the mature gilt and sow by a single injection of PMSG at the beginning of the follicular phase of the oestrous cycle (Hunter, 1964, 1966; Day, Longenecker, Jaffe, Gibson \& Lasley, 1967; Phillippo, 1968). The number of embryos at Days 25 to 30 of pregnancy was increased by treatment with PMSG, but the proportion of embryos surviving was generally greatly reduced in these animals. Treatment with PMSG could cause increased embryonic losses by the release of defective eggs or by creating an hormonal milieu that is unfavourable to embryonic development.

Doubling the normal food intake on the 1st day of oestrus has increased

* Published with the approval of the Director of the South Carolina Agricultural Experiment Station as a Technical Contribution.

$\dagger$ Present address: U.S. Department of Agriculture, A.R.S. Reproduction Laboratory, Building 200, BARC-East Beltsville, Maryland 20705, U.S.A.

$\ddagger$ Reprint requests to $\mathrm{Dr} D$. M. Henricks. 
ovulation rate and litter size in sows (Lodge \& Hardy, 1968). A fast of 24 to $72 \mathrm{hr}$ starting immediately after mating on the 1st day of oestrus was reported to have increased embryonic survival at Days 25 to 33 without affecting ovulation rate (Ray \& McCarty, 1965).

The present study was undertaken to examine the effects of PMSG and food intake on ovulation rate, the secretion of oestrogen, $\mathrm{LH}$, and progesterone, and the relationship of plasma hormone concentrations to the ovarian response to PMSG and embryonic survival.

\section{MATERIALS AND METHODS}

Seventy-one Duroc gilts, 8 to 10 months of age, were used. The occurrence of at least two consecutive oestrous cycles was checked for each gilt before assignment to a treatment group. The incidence of oestrus was determined daily at about 08.00 hours using a vasectomized boar and the 1st day of oestrus was designated Day 0 . Each gilt was fed daily with $1.8 \mathrm{~kg}$ of a ration containing $14 \%$ protein.

The experimental design was a randomized complete block with a $3 \times 2 \times 2$ factorial arrangement of the following treatments; three doses of PMSG $\{0,600$ or 1200 i.u.), two levels of food intake on the 1st day of oestrus (none or double the normal daily amount of food), and two times of autopsy post coitum (Day 6 or Day 24 p.c.). On Day 15 of the first oestrous cycle after the pretreatment period, the gilts received no injection (controls) or a single injection of 600 or 1200 i.u. PMSG (Equinex: Ayerst Laboratories). The hormone was dissolved in $2 \mathrm{ml}$ distilled water and injected subcutaneously behind the foreleg.

The gilts were mated to boars of proven fertility on the 1st day of oestrus after PMSG treatment and again 12 to $24 \mathrm{hr}$ later. The ovulation rate was determined at the time of autopsy by counting the number of $\mathrm{CL}$ which were dissected out of the ovaries and weighed. The embryos were collected on Day 6 by a method similar to that described by Perry \& Rowlands (1962) and the number of embryos at the late morula or early blastocyst stages of development were recorded. On Day 24, the uterine horns were dissected longitudinally and the number of embryos and the crown-rump lengths were recorded.

Blood was collected from the jugular vein at about 08.00 hours on the day of injection of PMSG, then daily including the 1st day of oestrus and subsequently on Days 3, 6, 12, 18 and 24 p.c. until autopsy. Progesterone concentration in blood plasma was determined by a competitive protein-binding assay using plasma from an adrenalectomized dog as the source of binding protein. A description of the assay procedures and data on the accuracy of the method have been reported (Henricks, Guthrie \& Handlin, 1972).

Total plasma oestrogen concentration was determined by radioimmunoassay as described previously (Henricks et al., 1972; Guthrie, Henricks \& Handlin, 1972).

Plasma LH was measured by the radioimmunoassay procedure reported by Niswender, Reichert \& Zimmerman (1970) who described its specificity and sensitivity. Antiserum against porcine LH (LER-786-4) was used at a dilution 
of $1: 32,000$. Porcine LH (LER-786-3) was iodinated with ${ }^{131}$ I-labelled sodium (Iso-Serve Division, Cambridge Nuclear Corp., Boston, Mass.) and was used as the standard hormone in the assay.

Ovulation rate, the number of normal embryos, the embryo losses, the total luteal weight, and the length of the oestrous cycle were analysed by analysis of variance with the $3 \times 2 \times 2$ factorial arrangement of treatments described above. The hormonal data were analysed individually using two of the treatment factors, the dose of PMSG and the level of feed intake. Individual treatment means were compared by Duncan's Multiple Range test when appropriate. The relationships between ovulation rate, embryo number, dose level of PMSG and plasma hormone levels were examined by regression and correlation analyses.

\section{RESULTS}

\section{Oestrous response}

Two gilts that had received 1200 i.u. PMSG and one which had received 600 i.u. PMSG did not exhibit oestrus after treatment. They were subsequently re-treated and mated. Administration of PMSG on Day 15 caused a significant reduction in the length of the treatment oestrous cycle $(P \leqslant 0.05)$; the mean difference between the length of the pretreatment cycles and the length of the treatment cycle for the gilts given 0,600 and 1200 i.u. PMSG was $0 \cdot 19,0.94$ and $1 \cdot 11$ days, respectively.

\section{Ovulation rate}

Examination at autopsy showed that ovulation had failed to occur in three gilts, all of which received 1200 i.u. PMSG. There was a significant increase in the number of ovulations from a mean \pm S.E. of $14.4 \pm 0.05$ in the control animals to $19 \cdot 2 \pm 1 \cdot 3$ and $26 \cdot 6 \pm 2 \cdot 7$ in the gilts given 600 and 1200 i.u. PMSG respectively. The linear regression coefficient was $1.062 \pm 0 \cdot 195$ ovulations/100 i.u. PMSG $(P \leqslant 0.001)$ with a coefficient of determination of 0.366 . As shown in Table 1 , the ovulation response to PMSG was greater $(P \leqslant 0 \cdot 05)$ in the gilts killed on Day 24 than at Day 6. The level of food intake on the 1st day of oestrus had no significant effect on ovulation rate.

\section{Embryo survival}

The effects of PMSG on the ovulation rate and on the number of embryos recovered at autopsy on Days 6 and 24 of pregnancy are shown in Table 1. Embryos were recovered from sixty-five of the seventy-one gilts $(91.5 \%$ conception rate). Gilts treated with 600 i.u. or 1200 i.u. PMSG had more embryos at both stages of pregnancy $(P \leqslant 0.05)$ than gilts not given PMSG. The PMSG treatment was also associated with a highly significant increase in embryo losses $(P \leqslant 0.001)$, the losses being greater at Day 24 than Day 6 $(P \leqslant 0.01)$.

The nature of the relationship between ovulation rate and the number of normal embryos and embryonic losses was different at the two stages of 


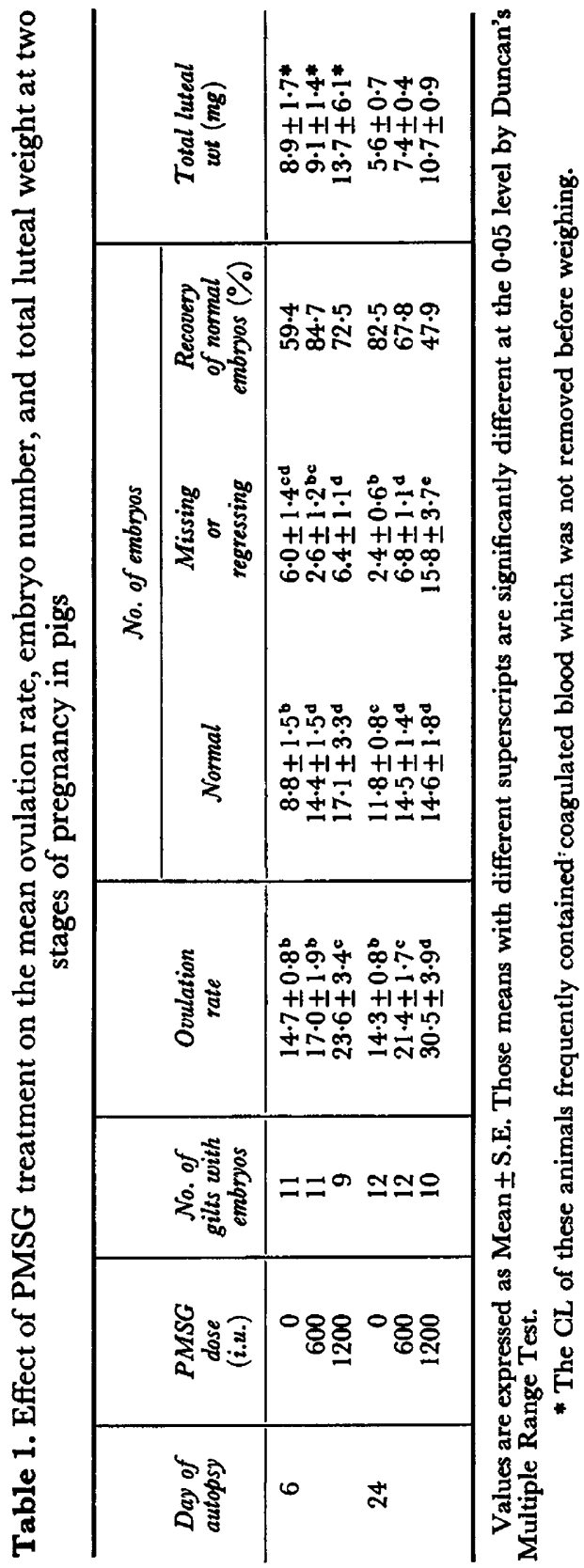


pregnancy. At Day 6, there was a highly significant linear correlation between ovulation rate and the number of normal embryos $(r=0.837, P \leqslant 0.001)$, but ovulation rate and embryo losses were not significantly correlated $(r=$ $0.293, P>0.05)$. At Day 24, there was a significant linear component in the relationship between ovulation rate and embryo number $(P \leqslant 0.01)$, and there was also a significant quadratic effect $(P \leqslant 0.01)$ which suggested a plateau in the number of embryos that could survive to Day 24 at higher ovulation rates. The relationship between embryo loss and ovulation rate at Day 24 exhibited a highly significant linear correlation $(r=0.892, P \leqslant 0.001)$ in contrast to that in gilts killed on Day 6.

\section{Plasma hormone levels}

The analysis of variance showed that the level of food intake on the 1st day of oestrus had no significant effect on plasma hormone concentrations. The effect of PMSG treatment on the mean plasma oestrogen, LH, and progesterone concentrations is shown in Text-fig. 1.

The plasma concentrations of oestrogen began to increase 3 to 4 days before the onset of oestrus. The mean oestrogen concentration for gilts receiving 1200 i.u. PMSG was significantly greater than the means for the other two groups on the day before oestrus $(P \leqslant 0.01)$ and on the 1st day of oestrus $(P \leqslant 0.05)$. Oestrogen levels were low on Day 3 after mating and the subsequent fluctuations around $20 \mathrm{pg} / \mathrm{ml}$ were not related to the PMSG treatment.

Mean plasma progesterone concentrations were significantly higher on Day $-4(P \leqslant 0.001)$ and Day $-3(P \leqslant 0.01)$ in the gilts receiving PMSG. After mating, progesterone secretion increased markedly by Day 6 . By Day 12, the mean and range for each group was $35 \cdot 1$ (16 to 59), 44.1 (26 to 67) and 62.6 (29 to 146) ng progesterone/ml for gilts treated with 0,600 or 1200 i.u. PMSG, respectively. The means for the first and last groups were significantly different $(P \leqslant 0.05)$, but neither was significantly different from that of the animals given 600 i.u. PMSG. After Day 12, the concentration of plasma progesterone generally declined in individual animals in all the groups, but on Days 18 and 24 the mean plasma. progesterone concentrations were greater in the two groups of PMSG-treated gilts than in the controls $(P \leqslant 0.05)$.

The mean plasma LH concentration on Day -3 was greater $(P \leqslant 0.05)$ in all the PMSG-treated animals (about $1.5 \mathrm{ng} / \mathrm{ml}$ ) than in the controls $(1.1$ $\mathrm{ng} / \mathrm{ml}$ ). The position was reversed on the day before oestrus; the difference between the mean for the controls and that for the animals given 600 i.u. was significant $(P \leqslant 0 \cdot 05)$. The magnitude of the preovulatory LH surge, as judged by the LH concentration on Day 0 , was not significantly affected by the PMSG treatment, and was not related to the ovulation rate. During pregnancy, the plasma $\mathrm{LH}$ values averaged about $1.5 \mathrm{ng} / \mathrm{ml}$ and there were no obvious trends.

The degree to which the concentration of plasma oestrogen and progesterone were correlated with ovulation rate, embryo number, and other data recorded at slaughter, are shown in Tables 2 and 3, respectively. The concentration of plasma progesterone on the day of PMSG injection bore no significant relationship to the subsequent ovulatory response. 

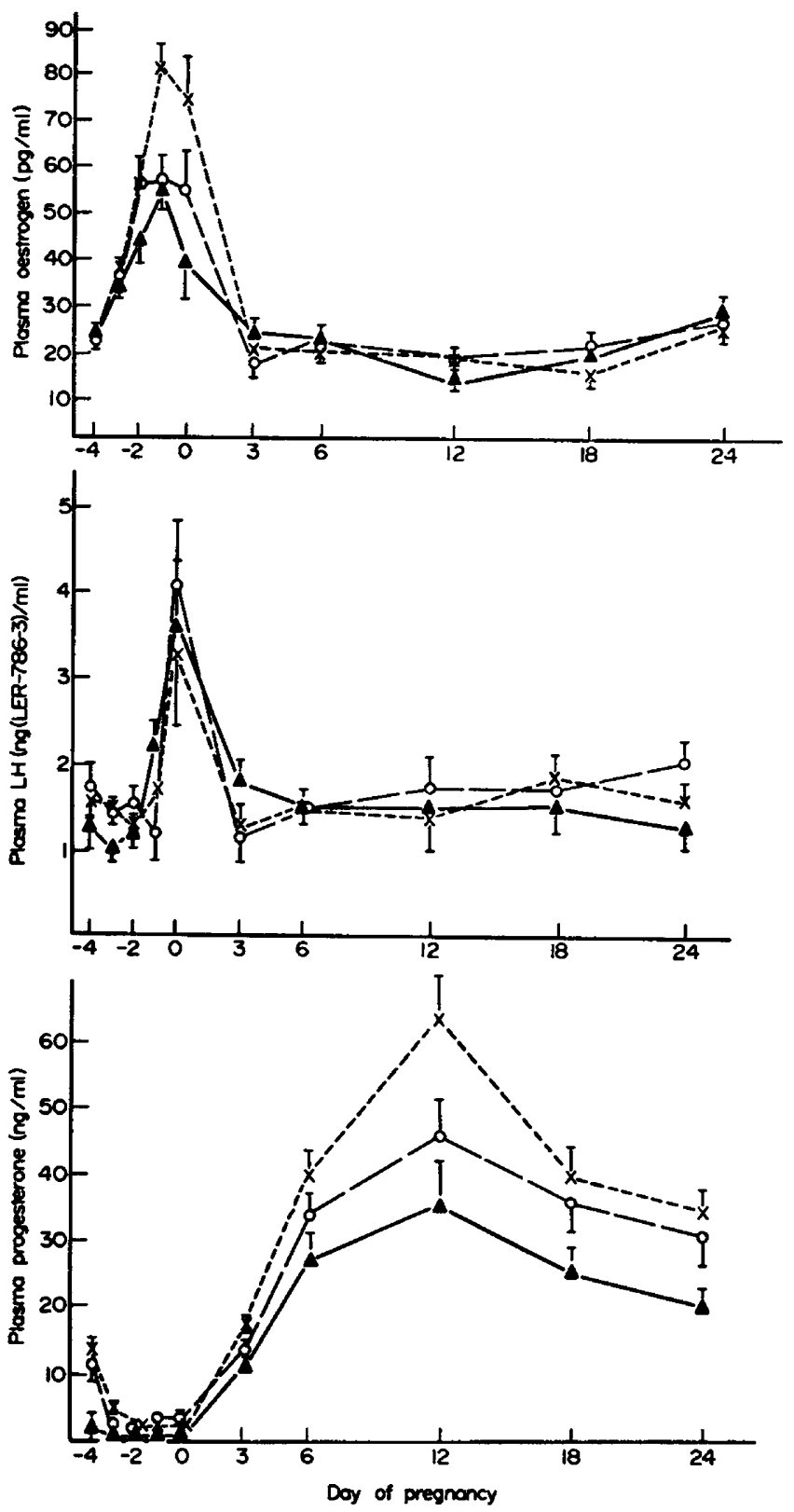

TExT-PIG. 1. Effects of PMSG on plasma oestrogen, LH and progesterone concentrations during pro-oestrus and the first 24 days after mating. Day 0 was the first day of oestrus. $\triangle$, No treatment with PMSG; 0,600 i.u. PMSG; $\times, 1200$ i.u. PMSG. 


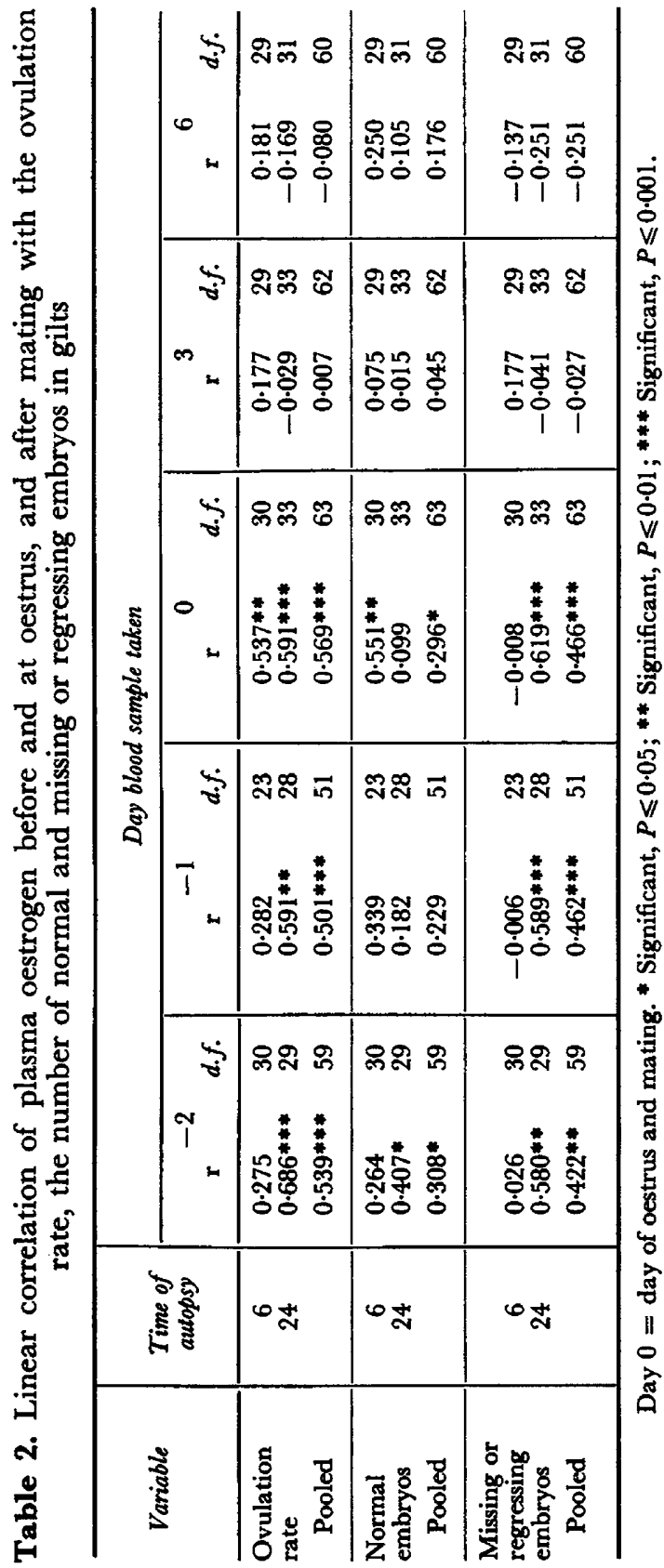




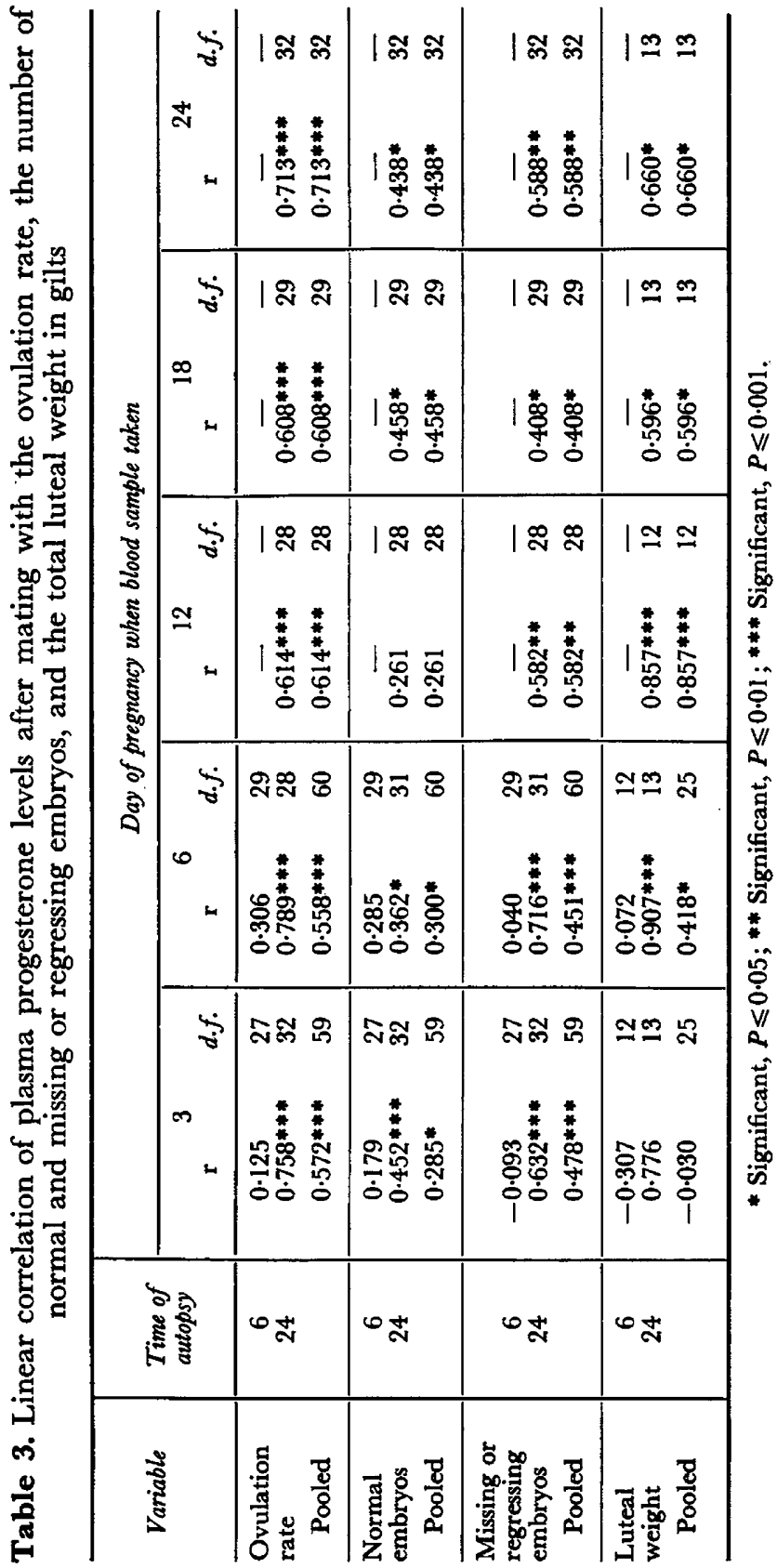




\section{DISGUSSION}

The superovulation obtained by PMSG treatment in this experiment was similar to that reported by Hunter (1964). Contrary to the results first published by Lodge \& Hardy (1968), doubling of the normal food intake on the lst day of oestrus had no effect on ovulation rate. The present results are in accordance with those of Brooks \& Cole (1971) who concluded that there is a threshold level above which it is very difficult to increase either ovulation rate or litter size by a short-term increase in food intake.

It was evident that when ovulation rate was increased by PMSG treatment, oestrogen secretion before ovulation was similarly increased. It is likely that this increased oestrogen secretion advanced the onset of oestrus and the preovulatory LH surge. During the first 24 days after mating, the increased numbers of CL in animals treated with PMSG were associated with high levels of circulating progesterone, ranging from 29 to $146 \mathrm{ng} / \mathrm{ml}$ on Day 12 compared to 16 to $59 \mathrm{ng} / \mathrm{ml}$ in control gilts.

The present results indicated that there was a difference in the relationship between the number of normal embryos and ovulation rate on Day 6 and on Day 24 p.c. The regression of embryo number at Day 6 on ovulation rate was a linear function, i.e. the number of embryos recovered continued to increase as ovulation rate increased. By contrast, the regression of embryo number at Day 24 on ovulation rate was best fitted by a quadratic function indicating that a limit had been imposed upon the number of embryos that could survive to Day 24 p.c. in gilts in which superovulation had been induced. Plasma progesterone concentrations after mating were correlated with embryonic losses as well as with ovulation rate and embryo number at Day 24 of pregnancy.

The exact nature of the limitation is not clear. Dziuk (1968) and Fenton, Bazer, Robison \& Ulberg (1969) reported that litter size at Days 25 to 40 was markedly reduced after potential litter size had been increased by ovum transfer. Such results suggested that the uterine environment might be limiting. However, data reported by Dziuk (1968) and Fenton et al. (1970) have indicated that intrauterine crowding caused by reduction of the uterine space available did not cause increased embryonic losses at this stage of pregnancy.

The fertilization rate in ova recovered from gilts in which superovulation was induced with PMSG appeared to be normal in the present experiment and in those of Hunter $(1964,1966)$. Some of the eggs ovulated after PMSG treatment may have failed to develop normally after fertilization because of inherent defects or because the uterine environment was adversely affected by the increased progesterone levels. Further experiments will be required to resolve this situation.

\section{ACKNOWLEDGMENTS}

The antiserum used in the RIA of total plasma oestrogen was supplied by Dr B. V. Galdwell, Yale University, New Haven, Connecticut. The antiserum against porcine LH (LER-786-4) was supplied by Dr G. D. Niswender, Colorado State University, Fort Collins, Colorado. Porcine LH (LER-786-3) 
was supplied by Dr L. E. Reichert, Jr, Emory University, Atlanta, Georgia. Thanks are due to Dr C. Polge, A.R.G. Unit of Reproductive Physiology and Biochemistry, Cambridge, England, who read and offered criticisms on this manuscript.

\section{REFERENCES}

Brooks, P. H. \& ColE, D. J. A. (1971) The effect of increasing feed intake for one day only during the oestrus period on the reproductive performance of sows. Anim. Prod. 13, 669.

Day, B. N., Longenecker, D. E., Jaffe, S. G., Gibson, E. W. \& Lasley, J. F. (1967) Fertility of swine following superovulation. F. Anim. Sci. 26, 777.

Dzrux, P. J. (1968) Effect of number of embryos and uterine space on embryo survival in the pig. f. Anim. Sci. 27, 673.

Fenton, F. R., Bazer, F. W., Robison, O. W. \& UlberG, L. C. (1969) Superinduction of gilts with 7 day pig embryos. F. Anim. Sci. 28, 144.

Fenton, F. R., Bazer, F. W., Robison, O. W. \& Ulberg, L. C. (1970) Effect of quantity of uterus on uterine capacity in gilts. F. Anim. Sci. 31, 104.

Guthrie, H. D., Henricks, D. M. \& Handin, D. L. (1972) Plasma estrogen, progesterone and luteinizing hormone prior to estrus and during early pregnancy in pigs. Endocrinology, 91, 675.

Henricks, D. M., Guthrie, H. D. \& Handisin, D. L. (1972) Plasma estrogen, progesterone and luteinizing hormone levels during the estrous cycle in pigs. Biol. Reprod. 6, 210.

Hunter, R. H. F. (1964) Superovulation and fertility in the pig. Anim. Prod. 6, 189.

Hunter, R. H. F. (1966) The effect of superovulation on fertilization and embryonic survival in the pig. Anim. Prod. 8, 457.

LODGE, G. A. \& HARDY, B. (1968) The influence of nutrition during oestrus on ovulation rate in the sow. 7. Reprod. Fert. 15, 329.

Niswender, G. D., Reichert, L. E. \& Zimmerman, D. R. (1970) Radioimmunoassay of serum levels of luteinizing hormone throughout the estrous cycle in pigs. Endocrinology, 87, 576.

Perry, J. S. \& Rowlands, I. W. (1962) Early pregnancy in the pig. F. Reprod. Fert. 4, 175.

Phillippo, M. (1968) Superovulation in the pig. Adv. Reprod. Physiol. 3. Logos Press, New York.

RAY, D. E. \& McCarTy, J. W. (1965) Effect of temporary fasting on reproduction in gilts. J. Anim. Sci. 24, 660 . 